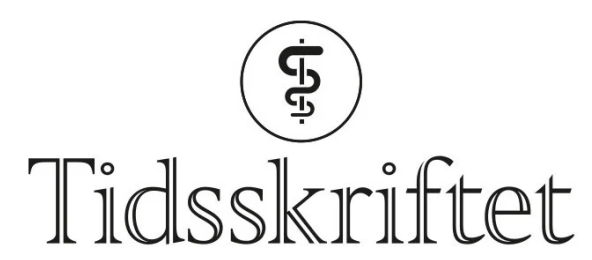

DEN NORSKE LEGEFORENING

\title{
Etiske dilemmaer i sykehusene under covid-19-pandemien
}

KRONIKK

\section{BERIT HOFSET LARSEN}

berihla@medisin.uio.no

Berit Hofset Larsen er kreftsykepleier, ph.d.-stipendiat og forsker ved Senter for medisinsk etikk, Universitetet i Oslo.

Forfatteren har fylt ut ICMJE-skjemaet og oppgir ingen interessekonflikter.

\section{MORTEN MAGELSSEN}

Morten Magelssen er ph.d., lege og førsteamanuensis ved Senter for medisinsk etikk, Universitetet i Oslo.

Forfatteren har fylt ut ICMJE-skjemaet og oppgir ingen interessekonflikter.

\section{OONA DUNLOP}

Oona Dunlop er dr.med., overlege på CBRNE-senteret og Akuttmedisinsk avdeling, Oslo universitetssykehus og leder for Klinisk etikkomité ved samme sykehus.

Forfatteren har fylt ut ICMJE-skjemaet og oppgir ingen interessekonflikter.

\section{REIDAR PEDERSEN}

Reidar Pedersen er ph.d., lege, filosof og professor ved Senter for medisinsk etikk, Universitetet i Oslo. Forfatteren har fylt ut ICMJE-skjemaet og oppgir ingen interessekonflikter.

\section{REIDUN FØRDE}

Reidun Førde er dr.med., lege og professor emeritus ved Senter for medisinsk etikk, Universitetet i Oslo.

Forfatteren har fylt ut ICMJE-skjemaet og oppgir ingen interessekonflikter.

Spesialisthelsetjenesten var ikke forberedt på de etiske dilemmaene som oppsto i starten av pandemien. Enkelte pasientgrupper fikk et dårligere helsetilbud som følge av pandemitiltak. Dette kan særlig ha rammet eldre og kronisk syke. 
Senter for medisinsk etikk ved Universitetet i Oslo har et nasjonalt koordineringsansvar for de klinisk etikk-komiteene som er etablert ved alle helseforetak. I mai 2020 sendte vi eposter til alle komiteene og spurte om hvilke problemstillinger de var blitt kontaktet om etter at pandemien startet, med særlig fokus på prioriteringsdilemmaer. Vi fikk svar fra 12 av 38 komiteer, og senteret har i tillegg blitt kontaktet direkte av helsepersonell. Dilemmaene har særlig vært knyttet til prioritering, smittevernhensyn, usikkert beslutningsgrunnlag samt risiko og belastning for helsepersonell.

\section{Prioritering}

Prioriteringsdilemmaer oppstår når ressursknapphet fører til at et formål må gå foran et annet eller man må avvike fra standarder for god praksis. De innrapporterte prioriteringsdilemmaene var særlig knyttet til knapphet på to ressurser: intensivkapasitet og smittevernutstyr.

Sykehusene forberedte seg i mars på å kunne ta imot svært mange covid-19-pasienter. Intensivkapasitet var en bekymring fordi man forventet at mange ville ha behov for respirator og annen langvarig intensivbehandling. De vanskelige prioriteringene oppsto ikke i samme grad som fryktet, men i starten av pandemien ble det tatt beslutninger basert på forventet ressursknapphet som førte til at pasienter ikke fikk behandling som det var ressurser til. Hvor mye vekt burde man legge på et mulig stort framtidig behov? Var det for eksempel riktig å tilby en ALS-pasient oppstart av permanent respiratorbehandling i starten av pandemien når det ville beslaglegge intensivkapasitet? Og hvor mye kapasitet burde man mobilisere, for eksempel gjennom anskaffelse av flere respiratorer og omdisponering av lokaler og personell? Omdisponering betød gjerne at annen behandling måtte reduseres eller stoppes. Noen spurte også om pårørende rutinemessig burde informeres om at oppstartet behandling kunne bli trukket tilbake hvis ressurstilgangen forverret seg.

Et spørsmål som vakte mye engasjement, var om det var riktig å ikke tilby intensivbehandling til pasienter over en viss alder. Dette ble aktualisert av at norske helsemyndigheter sendte til høring et forslag (med svært kort høringsfrist) om å nedprioritere pasienter over 80 år ved begrenset kapasitet og de over 60 år ved stor kapasitetsmangel (1). Dette ble senere endret til at alder ikke er et selvstendig prioriteringskriterium, men må sees i sammenheng med de etablerte prioriteringskriteriene. Mange hadde da lest høringsnotatet, og det festet seg et inntrykk av at alder ble tillagt stor vekt. Senter for medisinsk etikk mottok også rapporter om at eldre pasienter i primærhelsetjenesten kan ha blitt underbehandlet på grunn av klare anbefalinger om å behandle eldre pasienter i den institusjonen de befinner seg $\mathrm{i}(\underline{2})$. Samtidig gikk det bra med mange av dem som fikk intensivplass, inklusive enkelte sykehjemspasienter. Denne skjevheten ble forsterket av en svært høy dødelighet av covid-19 i sykehjem (3) -(5) og en lavere prioritering av smittevern i sykehjemmene enn i sykehusene.

Pasienter med andre tilstander enn covid-19 fikk i en del tilfeller et dårligere tilbud som følge av forventede og reelle kapasitetsproblemer samt dårlig organisering. Dette rammet særlig pasienter med kroniske lidelser. Et eksempel er enkelte pasienter med alvorlig depresjon som ikke lenger fikk tilbud om elektrokonvulsiv terapi (ECT), hvis pasienten hadde forhøyet risiko for komplikasjoner og det var behov for god tilgang på intensivressurser. For noen førte det til forverring av tilstanden og behov for en enda mer belastende og ressurskrevende behandling enn de i utgangspunktet hadde trengt, for eksempel langvarig tvangsinnleggelse på psykiatrisk avdeling.

Noen steder ble den polikliniske virksomheten midlertidig nedlagt for å frigjøre ressurser. Dermed ble det et brudd i oppfølgingen av sårbare pasientgrupper. Andre steder ble konsultasjonene mindre hyppige eller gjort via telefon eller digitalt. Det er behov for mer 
kunnskap om hvordan det har gått med disse pasientene. Men mye tyder på at mange pasienter og pårørende fikk et dårligere tilbud. Risikoen for forverring som følge av dette har skapt dilemmaer for helsepersonell.

\section{"I pandemiens første fase førte manglende kunnskap og manglende \\ informasjonsflyt til at beslutninger måtte tas på usikkert grunnlag»}

Prioritering av smittevernutstyr ble også et stort dilemma. I begynnelsen av pandemien var det en reell, akutt mangel på godkjent smittevernutstyr, og fordelingen av smittevernutstyr mellom sykehus og institusjoner var heller ikke godt koordinert. Flere steder hadde man en beholdning for kun noen dagers forbruk, uten å vite sikkert når eller om det kom påfyll. Skulle man bruke smittevernutstyr i alle situasjoner hvor det var ansett som god praksis, for så å risikere å gå tom? Eller skulle man spare utstyret til de mest risikofylte situasjonene, som ved bekreftet smitte og ved aerosolgenererende prosedyrer? Mange steder så man seg nødt til å avvike fra etablerte standarder, med det resultat at pasienter og personale ble utsatt for smitte.

\section{Smittevern}

Dilemmaene som følge av smittevernhensyn handlet særlig om besøksrestriksjoner og at pasienter fikk dårligere behandling enn ellers. I flere tilfeller var det vanskelig å vekte hjelpeplikt mot smitterisiko for personalet. Noen behandlingsformer, som ikke-invasiv ventilasjonsstøtte (NIV) og oksygenbehandling med høy luftstrøm, innebærer $\emptyset \mathrm{kt}$ smitterisiko for personalet på grunn av aerosoldannelse. Dette, sammen med manglende smittevernutstyr og usikkerhet om nytten av disse tiltakene for covid-19-pasienter, gjorde at disse behandlingsformene noen steder ikke ble tilbudt til covid-19-positive eller dem med uavklart covid-19-status. Spesielt uheldig var dette for pasientgruppen som heller ikke fikk tilbud om respiratorbehandling. Alvorlige utfall som følge av dette, kan ikke utelukkes. Er den potensielle nytten av ikke-invasiv ventilasjonsstøtte så tungtveiende at $\emptyset \mathrm{kt}$ smitterisiko burde blitt akseptert?

Smittevernhensyn har også ført til «nye» dilemmaer rundt bruk av tvang. Tvangstiltak vil ofte innebære nærkontakt, og således smitterisiko. Flere har rapportert om mindre bruk av tvang i situasjoner der tvang var vurdert å være i pasientens interesse, for eksempel i behandling av alvorlig anoreksi og selvskading, der det å holde pasienten kan hindre forverring og i verste fall $\mathrm{d} ø \mathrm{~d}$. For pasienter med manglende forståelse eller samarbeidsevne, som ved demens eller alvorlig psykisk sykdom, har tvangsbruken økt.

Rutinemessig testing før innleggelse er én måte å forhindre at smitte kommer inn $\mathrm{i}$ avdelinger. Nytten av å teste symptomfrie personer er imidlertid usikker. I en komité ble det drøftet hvorvidt det var riktig rutinemessig å teste barn i kreftbehandling og deres ledsager før innleggelse når de ikke hadde symptomer på covid-19. Mange av barna kom ukentlig til behandling, og sykepleierne fortalte at mange av dem opplevde testingen som plagsom og skremmende. Kunne nytten av rutinemessig testing rettferdiggjøre belastningen det medførte for disse barna?

\section{«Siden man ikke forsøkte avansert behandling, ble oppfatningen om dårlig prognose en selvoppfyllende profeti»}

Tidlig i pandemien ble det innført strenge besøksrestriksjoner ved de fleste sykehus - både for å beskytte sårbare pasienter og for å forhindre at personalet ble smittet eller måtte i karantene. Besøk ville dessuten kreve forbruk av smittevernutstyr som det var knapphet på. Selv om hensikten med restriksjonene var god, opplevde mange det særlig problematisk at alvorlig syke og døende ikke fikk ha sine nærmeste rundt seg, og helsepersonell strakk seg 
langt for å finne løsninger. Teknologien gir i dag muligheter som tidligere ikke var tilgjengelig, men som reiser nye etiske spørsmål. Bør helsepersonell for eksempel kunne fotografere en ikke-samtykkekompetent pasient på intensivavdeling og sende bildet til ektefelle etter dennes ønske? Til å begynne med var det bred oppslutning om besøksrestriksjonene, men etter hvert spurte flere seg om de menneskelige omkostningene ble for store. Manglende avklaring av disse spørsmålene har ført til ulik praktisering av besøksrestriksjonene på sykehusene, noen har vært unødig strenge.

\section{Usikkert beslutningsgrunnlag}

I pandemiens første fase førte manglende kunnskap og manglende informasjonsflyt til at beslutninger måtte tas på usikkert grunnlag. For eksempel trodde man som nevnt at covid19-pasienter ikke ville ha nytte av ikke-invasiv ventilasjonsstøtte (므). På flere sykehus ble det derfor besluttet at pasienter som ikke var aktuelle for respiratorbehandling, heller ikke skulle få annen intensivbehandling. Senere viste det seg at ikke-invasiv ventilasjonsst $\varnothing$ tte kunne være et godt alternativ for mange. Det betyr at en gruppe eldre covid-19-pasienter i pandemiens første fase ble fratatt en behandling vi senere fant ut at kunne ha vært gunstig for dem. Kanskje burde vi vært raskere med å prøve ut denne type ventilasjonsstøtte for de pasientene som ikke var aktuelle for respiratorbehandling.

Føringer fra helsemyndighetene og lokal ledelse endret seg svært raskt den første tiden, nærmest fra time til time. Oppdatert informasjon nådde ikke ut i samme takt til alle som sto med vanskelige beslutninger. Dette førte til at prioritering av intensivplasser og sykehusinnleggelser i starten ble praktisert varierende og for strengt. Pasienter som ellers ville ha blitt tilbudt intensivplass, ble behandlet på sengepost, og færre ble innlagt med andre sykdommer.

\section{Risiko og belastning for helsepersonell}

Kompetent personell er helsetjenestens viktigste ressurs. Pandemien har aktualisert mange spørsmål om risiko og belastning for denne gruppen. Hvor mye risiko skal helsepersonell forventes å utsette seg for, særlig når det mangler smittevernutstyr? Hvordan ivareta helsepersonell som selv er i risiko for alvorlig forl $\emptyset p$ av covid-19-sykdom eller har familiemedlemmer som er det? Hvordan vekte hensynet til ansatte i risikogruppe mot ansatte som må bære byrden av økt arbeidsbelastning? Hvordan snakke om risiko uten å skape mer frykt? Hvordan støtte helsepersonell under moralsk og emosjonelt stress i en tid med usikkerhet, risiko for egen helse, høy arbeidsbelastning og ressursmangel? Noen sykehus ga dette temaet særlig oppmerksomhet.

\section{«Tause tapere»}

Enkelte pasientgrupper fikk altså et dårligere behandlingstilbud under første fase av pandemien. For noen har endringer i helsetilbudet trolig hatt mindre betydning. Andre kan ha fătt store ekstrabelastninger som vi enda ikke vet konsekvensene av. For enkelte kan det ha vært fatalt. Blant covid-19-pasienter var det særlig eldre og beboere i sykehjem som ikke fikk tilbud om sykehusinnleggelse. Mange av disse tilhører høyrisikogruppen for alvorlig forløp av covid-19. Denne gruppen var også antatt å ha minst nytte av avansert behandling. Det kan derfor ha vært en riktig vurdering at mange av disse var best tjent med god omsorg og pleie «der de var» (2). Men siden man ikke forsøkte avansert behandling, ble oppfatningen om dårlig prognose en selvoppfyllende profeti. En utfordring var også at de nasjonale prioriteringskriteriene førte til at denne gruppen ble vurdert under ett. Flere pasienter fikk ikke en individuell vurdering, i strid med rettferdighetsprinsippet og 
pasientrettighetene ((7.), § 2-2). I tillegg kan noen pasienter ha fått et dårligere tilbud i livets siste fase som følge av mangel på kompetanse på lindrende behandling samt fravær av nære pårørende.

\section{«Det er etter vårt syn påfallende hvor lett man har nedskalert visse}

tjenester»

Det er tankevekkende om pasienter med andre sykdommer enn covid-19, slik som eldre pasienter med kronisk obstruktiv lungesykdom, alvorlig depresjon og ruslidelser, fikk et dårligere tilbud under pandemien. Det bør uansett undersøkes nærmere om pasientgrupper som tidligere har blitt relativt lavt prioritert, ble rammet ekstra hardt av omprioriteringene. Det er etter vårt syn påfallende hvor lett man har nedskalert visse tjenester.

Pårørende er en gruppe som har fått lite oppmerksomhet i forbindelse med pandemien. Mange har lidd under å ikke kunne være hos sine eldre, syke og døende. Andre har fått økt belastning gjennom økt omsorgsansvar som følge av nedskalering av tjenester. I psykisk helsevern synes samarbeidet med nære pårørende å ha blitt redusert som følge av smitteverntiltak, mens de pårørendes belastning har blitt større.

\section{Konklusjon}

Pandemiens første fase medførte flere etiske dilemmaer i sykehusene. Dilemmaene dreide seg særlig om prioriteringsvansker, smittevernhensyn og beslutninger på usikkert grunnlag samt balansegangen mellom helsepersonells hjelpeplikt og risiko og belastninger de ble utsatt for. I tillegg ser man i ettertid at tiltakene som ble innført tidlig i pandemien kan ha ført til at enkelte pasientgrupper, særlig eldre og kronisk syke, fikk et dårligere helsetilbud.

\section{LITTERATUR}

1. Helsedirektoratet. Høringsnotat 17.mars 2020: Prioritering av helsehjelp i Norge under covid-19 epidemien. https://www.helsedirektoratet.no/veiledere/koronavirus/kapasitet-ihelsetjenesten/prioritering-av-helsehjelp-i-norge-under-covid-19-pandemien Lest 9.11.2020.

2. Helsedirektoratet. Prioriteringsnotat 25. mars 2020: Prioritering av helsehjelp i Norge under covid19-pandemien. https://www.helsedirektoratet.no/tema/beredskap-og-

krisehandtering/koronavirus/prioriteringsnotat-prioritering-av-helsehjelp-i-norge-under-covid-19pandemien Lest 9.11.2020.

3. McMichael TM, Currie DW, Clark S et al. Epidemiology of Covid-19 in a Long-Term Care Facility in King County, Washington. N Engl J Med 2020; 382: 2005-11. [PubMed][CrossRef]

4. Socialstyrelsen i Sverige. Statistik om covid-19 bland äldre efter boendeform.

https://www.socialstyrelsen.se/statistik-och-data/statistik/statistik-om-covid-19/statistik-om-covid-19bland-aldre-efter-boendeform/ Lest 9.11.2020.

5. Arulkumaran N, Brealey D, Howell D et al. Use of non-invasive ventilation for patients with COVID19: a cause for concern? Lancet Respir Med 2020; 8: e45. [PubMed][CrossRef]

6. Kittang BR, Hofacker SV, Solheim SP et al. Utbrudd av covid-19 ved tre sykehjem i Bergen. Tidsskr Nor Legeforen 2020; 140. doi: 10.4045/tidsskr.20.0405. [PubMed][CrossRef]

7. LOV-1999-07-02-63. Lov om pasient- og brukerrettigheter (pasient- og brukerrettighetsloven). https://lovdata.no/dokument/NL/lov/1999-07-02-63 Lest 9.11.2020. 
Publisert: 11. desember 2020. Tidsskr Nor Legeforen. DOI: 10.4045/tidsskr.20.0851

Mottatt 21.10.2020, første revisjon innsendt 30.10.2020, godkjent 9.11.2020.

(C) Tidsskrift for Den norske legeforening 2023. Lastet ned fra tidsskriftet.no 26. april 2023. 